Volume 6, No. 2 Oktober 2021, Hal 90 - 94

\author{
DETERMINATION OF PROTEIN LEVELS OF WHITE OYSTER \\ MUSHROOM (Pleurotus ostreatus) AND MEANG MUSHROOM (Volvariella volvaceae) WITH THE KJELDAHL \\ METHOD
}

\title{
PENETAPAN KADAR PROTEIN JAMUR TIRAM PUTIH (Pleurotus ostreatus) DAN JAMUR MERANG (Volvariella volvaceae) DENGAN METODE KJELDAHL
}

\begin{abstract}
Dara Callista Dinda Amelia, Diah Astika Winahyu*
Prodi DIII Analis Farmasi dan Makanan Universitas Malahayati

Email : astika.diah@gmail.com

ABSTRACT

Mushrooms are plants that contain high levels of vitamin B complex and are the only non- animal foods with vitamin $D$ content that are used for bone health. White oyster mushrooms and straw mushrooms have a lot of nutritional content, one of which is protein. Proteins are complex organic compounds of high molecular weight. Quantitative testing with the Kjedahl method has three stages, namely destruction, distillation, and titration. The results of the quantitative test using the Kjedahl method showed that oyster mushrooms had a protein content of $2.39 \%$ and straw mushrooms were $1.46 \%$.
\end{abstract}

Keywords : White Oyster Mushroom, Straw Mushroom, Protein, Kjedahl Method.

\section{ABSTRAK}

Jamur merupakan tumbuhan yang mengandung tinggi vitamin B kompleks dan merupakan satu-satunya bahan pangan non-animal dengan kandungan vitamin $D$ yang dipergunakan untuk kesehatan tulang. Jamur tiram putih dan jamur merang memiliki banyak kandungan gizi salah satunya adalah protein. Pengujian secara kuantitatif dengan metode kjedahl mempunyai tiga tahapan yaitu destruksi, destilasi, dan titrasi. Hasil dari uji kuantitatif dengan metode kjedahl menunjukan bahwa jamur tiram memiliki kandungan protein sebesar 2,39\% dan jamur merang sebesar 1,46\%.

Kata kunci : Jamur Tiram Putih, Jamur Merang, Protein, Metode Kjedahl.

\section{PENDAHULUAN}

Jamur merupakan bahan pangan alternatif yang disukai lapisan masyarakat.Di Indonesia memiliki keragaman jenis jamur.Jamur konsumsi merupakan salah satu komoditas pangan yang saat ini digemari oleh semua kalangan masyarakat. [2].

Jamur dikonsumsi masyarakat dengan cara di tumis, di bakar, atau dijadikan sebagai alternatif bumbu penyedap alami. penggunaan jamur sebagai alternatif bumbu penyedap alami selain memberikan rasa gurih dan lezat pada masakan juga memberikan berbagai manfaat kesehatan sehingga jamur sering disebut sebagai makanan fungsional. Jamur mengandung rendah natrium serta tinggi potasium sehingga dapat mempertahankan tekanan darah tetap stabil.Jamur juga membantu mencegah penyakit kronis, diabetes dan mengurangi berat badan karena tidak mengandung kolesterol, rendah kalori, mengandung antioksidan, dan serat makanan seperti kitin dan betaglukan.

Jamur juga sangat berguna untuk diet vegetarian karena jamur mengandung tinggi senyawaan protein

berupa asam amino esensial dimana sangat diperlukan untuk kesehatan manusia.Selain manfaat tersebut, jamur merupakan tumbuhan yang mengandung tinggi vitamin $B$ kompleks dan merupakan satu-satunya bahan pangan non-animal dengan kandungan vitamin $\mathrm{D}$ yang dipergunakan untuk kesehatan tulang [5].

Jamur tiram putihmerupakan jamur komsumsi yang termasuk dalam kelas basidiomycetes. Sebagai komoditas yang dapat dikonsumsi, jamur tiram memilikiciri tubuh buah berwarna putih hingga krem dan tudungnya berbentuk setengah lingkaran, mirip dengan cangkang tiram dengan bagian tengah yang sedikit cekung.Jamur tiram puth mengandung lemak, 
karbohidrat, protein, dan serat.Di samping itu jamur tiram mengandung vitamin $B$ [1].

Jamur merang dengan nama ilmiah Volvariella volvaceae $L$. merupakan salah satu cendawan yang sudah mulai dibudidayakan dan dikembangkan karena memiliki nilai gizi dan manfaat kesehatan yang baik bagi manusia. jamur merang dapat berfungsi untuk mencegah kanker, mencegah anemia dan tekanan darah tinggi. Di Indonesia, budidaya jamur merang termasuk relatif baru dimana mulai dibudidayakan pada tahun 1995. Jamur merang merupakan sumber proteindan mineral yang baik dengan kandungan kaliumdan fosfor tinggi sedangkan kandunganlemaknya rendah [4].

Dari hasil penelitian sebelum nya oleh Jamur tiram dan jamur merang memiliki banyak kandungan gizi, salah satunya adalah protein. Protein adalah senyawa organik kompleks berbobot molekul tinggi yang merupakan polimer dari monomer - monomer asam amino yang dihubungkan satu sama lain dengan ikatan peptida. Molekul protein mengandung karbon, hidrogen, oksigen, nitrogen dan kadang kala sulfur serta fosfor [3].

Manfaat protein dalam tubuh antara lain adalah pembentukan senyawa-senyawa penting tubuh, seperti hormon, enzim, hemoglobin, dan pembentuk antibodi tubuh, yaitu zat yang digunakan untuk memerangi organisme atau bahan asing lain yang masuk dalam tubuh, termasuk kemampuan untuk menetralkan bahan- bahan beracun kemampuan ini sangat menentukan daya tahan tubuh seseorang (Widodo, 2010).

Metode Kjeldahl digunakan secara luas di seluruh dunia dan masih merupakan metode standar yang digunakan untuk penetapan kadar protein. Sifatnya yang universal, presisi tinggi dan reprodusibilitas baik membuat metode ini banyak digunakan untuk penetapan kadar protein. Metode Kjeldahl memiliki kekurangan yaitu purina, pirimidina, vitamin-vitamin, asam amino besar, dan kreatina ikut teranalisis dan terukur sebagai nitrogen. Walaupun demikian, cara ini masih digunakan dan dianggap cukup teliti digunakan sebagai penentu kadar protein (Winarno, 2014).

Berdasarkan latar belakang diatas, penulis tertarik untuk melakukan penelitian tentang "penetapan kadar protein jamur tiram (Pleurotus ostreatus) dan jamur merang (Volvariella volvaceae) dengan metode kjeldahl" dengan tujuan mengetahui seberapa besar kadar protein dari kedua jamur tersebut.

\section{METEDEOLOGI PENELITIAN}

Penelitian ini dilakukan pada bulan Juni
Laboratorium Universitas Malahayati, Bandar Lampung.
Alat dan Bahan
Alat
a) Buret $50 \mathrm{~mL}$
b) Labu destilasi dan kondensor
c) Erlenmeyer
d) Mortir dan stemper
e) Pipet ukur $5 \mathrm{~mL}, 10 \mathrm{~mL}, 25 \mathrm{~mL}$
f) Lampu spiritus
g) Labu takar $250 \mathrm{~mL}, 500 \mathrm{~mL}$
h) Timbangan
i) Beaker glass $100 \mathrm{~mL}, 250 \mathrm{~mL}, 500 \mathrm{~mL}$
j) Klem, statif dan ring stand

Bahan
a) Jamur tiram merang putih dan jamur
b) $\mathrm{CuSO} 4$ encer
c) $\mathrm{NaOH}$ encer
d) $\mathrm{H} 2 \mathrm{SO} 4$ pekat
e) Kristal CuSO4
f) Kristal K2SO4
g) $\mathrm{NaOH} 0,1 \mathrm{~N}$
h) $\mathrm{HCl} 0,1 \mathrm{~N}$
i) Fenolftalein $1 \%$
j) Aquadest Prosedur Penelitian Preparasi

\section{Prosedur Penelitian Preparasi}

Jamur tiram putih dan jamur merang di bersihkan dengan menggunakan tissue hingga semua kotoran yang ada pada jamur hilang. Jamur kemudian di haluskan dengan blender.

Jamur tiram putih dan jamur merang yang sudah di haluskan di timbang 2 gram untuk selanjutnya dilakukan penelitian.

\section{Uji Kualitatif}

Larutan protein dibuat alkalis dengan $\mathrm{NaOH}$ encer. Ditambah larutan CuSO4 encer. Uji ini dilakukan untuk menunjukkan adanya senyawa- senyawa yang mengandung gugus amida asam yang beradabersama gugus amida yang lain. Uji ini memberikan reaksi positif yang ditandai dengan timbulnya warna merah violet atau biru violet.

\section{Uji Kuantitatif}

Standardisasi larutan $\mathrm{NaOH} 0,1 \mathrm{~N}$ dengan Kalium biftalat ditimbang seksama $100 \mathrm{mg}$ kalium biftalat $\mathrm{P}$ 
yang sebelumnya telah dihaluskan dan dikeringkan pada suhu $120^{\circ} \mathrm{C}$ selama 2 jam.

Larutkan dalam $25 \mathrm{~mL}$ aquadest bebas $\mathrm{CO} 2$.

Ditambahkan 2 tetes indikator fenilftalein 1\% dan titrasi dengan larutan $\mathrm{NaOH} 0,1 \mathrm{~N}$ hingga terjadi warna merah muda konstan.

Dilakukan secara triplo

Destruksi

Ditimbang kurang lebih 2 gram sampel yang telah dihaluskan hingga homogen, kemudian dimasukkan ke dalam labu kjeldahl. Ditambahkan 5 gram K2So4, 0,2 mg CuSO4 dan 20mL H2SO4 pekat, digojog hingga tercampur. Dipanaskan dengan api langsung dalam lemari asam, mula-mula dengan api kecil dan setelah asap hilang api dibesarkan. Pemanasan diakhiri hingga cairan berwarna hijau jernih

\section{Tahap Destilasi}

Sebanyak tiga kali dan dilakukan penetapan blanko.

\section{Cara Analisa Data}

Analisa data penelitian Penetapan kadar protein total dihitung dengan menggunakan rumus sebagai berikut:
$\mathrm{N}(\%)$ (volume $\mathrm{NaOH}$ blanko - volume $\mathrm{NaOH}$ sampel) di dinginkan, kemudian dibagi bobotsampel (gram) $x 1000$ ditambahkan $100 \mathrm{~mL}$ aquadest, beberapa batu didih dan ditambahkan perlahan-lahan larutan $\mathrm{NaOH} 50 \%$ sbanyak $50 \mathrm{~mL}$ sampai cairan bersifat basa.

Segera dipasang labu pada alat destilasi, lalu dipanaskan dengan cepat sampai amonia menguap sempurna. Tampung destilat dengan erlenmeyer yang berisi $50 \mathrm{~mL} \mathrm{HCl} 0,1 \mathrm{~N}$ dan 3 tetes indikator fenolftalein 1\%. Ujung pipa kaca destilator dipastikan masuk dalam larutan $\mathrm{HCl} 0,1 \mathrm{~N}$. Destilasi diakhiri dengan tetesan destilat tidak bereaksi basa

\section{Tahap Titrasi}

Hasil destilasi dititrasi dengan larutan standar

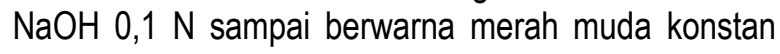
tidak hilang selama 30 detik Kemudian dilakukan pengulangan $\times \mathrm{NNaOH} \times 14,008 \times 100 \%$

\section{HASILPENELITIAN}

Pada penelitian kadar protein jamur tiram putih dan jamur merang secara kualitatif dan kuantitatif dengan metode kjedahl didapatkan hasil sebagai berikut

Tabel 1.Hasil Uji Biuret Jamur Tiram Putih dan jamur merang

\begin{tabular}{|c|c|c|}
\hline Pengujian & Warna & Hasil \\
\hline sampel & Biru Violet & + \\
\hline sampel & Biru Violet & + \\
\hline $\begin{array}{c}\text { Kontrol positif } \\
(+)\end{array}$ & Biru Violet & + \\
\hline $\begin{array}{c}\text { Kontrol negatif } \\
(-)\end{array}$ & Hijau & - \\
\hline
\end{tabular}




\title{
JURNAL ANALIS FARMASI
}

Volume 6, No. 2 Oktober 2021, Hal 90 - 94

\begin{abstract}
Hasil Uji Kuantitatif Dengan Metode Kjedahl
Pada penelitian kadar protein jamur tiram dan jamur merang secara kuantitatif menggunakan metode kjedahl didapatkan hasil sebagai berikut ;
\end{abstract}

Tabel 2. Hasil Penetapan Kadar Protein Jamur Tiram Dan Jamur Merang

\begin{tabular}{|c|c|c|c|}
\hline Sampel & Pengulangan & Protein (\%) & Rata- Rata (\%) \\
\hline $\begin{array}{c}\text { Jamur } \\
\text { Tiram } \\
\text { Putih }\end{array}$ & 1 & 1,817 & \\
\cline { 2 - 3 } & 2 & 2,490 & \multirow{2}{*}{2,39} \\
\cline { 2 - 3 } & 3 & 2,886 & \\
\hline Jamur \\
Merang & 1 & 1,54 & \multirow{2}{*}{1,46} \\
\cline { 2 - 3 } & 2 & 1,311 & \\
\cline { 2 - 3 } & 3 & 1,54 & \\
\hline
\end{tabular}

\section{PEMBAHASAN}

Sebelum melakukan penetapan kadar protein secara Kjeldahl, dilakukan uji kualitatif yang bertujuan untuk mengetahui sampelmengandung protein dengan menggunakan metode biuret ditandai dengan warna biru violet.

Uji kualitatif dengan mentode biuret dilakukan dengan cara penambahan $\mathrm{CuSO} 4$ dan $\mathrm{NaOH}$ pada sampel, kontrol positif dan kontrol negatif. Kontrol posistif yang digunakan adalah putih telur sedangkan kontrol negatif yang di gunakan adalah aquades. Dari hasil uji kualitatif dengan menggunakan metode biuret kontrol positif menunjukan warna biru violet, sampel jamur tiram putih dan jamur merang menunjukkan warna yang sama sedangkan kontrol negatif yaitu aquades menunjukkan warna hijau. Maka dari hasil uji biuret sampel jamur tiram dan jamur merang posistif mengandung protein.

Pada tahap destruksi, sampel dipanaskan dalam asam sulfat pekat sehingga terjadi destruksi menjadi unsur-unsurnya. Elemen karbon $(\mathrm{C})$ dan hidrogen $(\mathrm{H})$ teroksidasi menjadi karbon monoksida (CO), karbondioksida (CO2), dan air ( $\left.\mathrm{H}_{2} \mathrm{O}\right)$. Elemen Nitrogen akan berubah menjadi amonium sulfat. Banyaknya asam sulfat yang digunakan untuk destruksi diperhitungkan terhadap kandungan protein, karbohidrat dan lemak.Untuk mempercepat destruksi maka ditambahkan katalisator yaitu CuSO4 dan

K2SO4. Proses destruksi diakhiri jika larutan telah menjadi warna hijau jernih.

Pada tahap destilasi, amonium sulfat dapat dipecah menjadi amonia, yaitu dengan penambahan larutan $\mathrm{NaOH}$ sampai alkalis dan dipanaskan.Amonia yg dibebaskan ditangkap oleh larutan asam.Asam yang dapat dipakai adalah $\mathrm{H}_{2} \mathrm{SO}$ 4.Agar kontak antara larutan asam dengan amonia berjalan sempurna, maka ujung selang pengalir destilat harus tercelup kedalam larutan asam.

Destilasi diakhiri jika semua amonia sudah terdestilasi sempurna menggunakan indikator fenolflatein sebagai indikator penunjuk.

Apabila penampung destilat yang digunakan adalah larutan asam sulfat, maka sisa asam sulfat yang tidak bereaksi dengan amonia dititrasi dengan $\mathrm{NaOH} 0,1 \mathrm{~N}$ menggunakan indikator fenolftalein $1 \%$ sampai terjadi titik akhir yang ditandai dengan berubahnya warna larutan menjadi warna merah muda konstan. Selisih jumlah titrasi sampel dan blanko merupakan jumlah nitrogen.

Pada peneliatian ini sampel jamur tiram putih pada pengulagan pertama memiliki hasil akhir titrasi yang 
cukup jauh dengan hasil pengulangan kedua dan ketiga dikarenakan saat menimbang sampel lebih dari 2,000 gram yaitu 2,004 sedangkan sampel untuk pengulangan kedua dan ketiga adalah 2,001 dan 2,000 gram. Hasil dari penimbangan tersebut membuat lebih banyak destilat sehingga saat dititrasi titran yang diperlukan lebih banyak dibandingkan pengulangan kedua dan ketiga.

Hasil dari penelitian Penetapan kadar protein total jamur tiram putih (Pleurotus ostreatus) dan jamur merang (Volvariella volvaceae) menggunakan metode Kjeldahl didapatkan kadar rata-rata protein pada jamur tiram putih adalah 2,39\% dan kadar rata-rata protein pada jamur merang sebesar $1,46 \%$. dari hasil tersebut menunjukan bahwa Jamur tiram putih mengandung protein lebih besar daripada jamur merang

\section{KESIMPULAN}

Dari hasil penelitian penetapan kadar protein jamur tiramputih (Pleurotus ostreatus) dan jamur merang (Volvariella volvaceae) dengan metode kjeldahl, dapat disimpulkan bahwa :

1. Kadar protein pada jamur tiram putih (Pleurotus ostreatus) sebesar 2,39 \%,

2. Kadar protein pada jamur merang (Volvariella volvaceae) sebesar $1,46 \%$.

3. Jamur tiram dan jamur merang memiliki kandungan protein

\section{SARAN}

1. Untuk penelitian selanjutnya perlu dilakukan penelitian dengan metode lain seperti spektrofotomet

2. Masyarakat dapat mengonsumi jamur tiram dan jamur merang untuk memenuhi kebutuhan protein tubuh.

\section{DAFTAR PUSTAKA}

Cahyana,Y,A.,Muchrodji.,danM.Bakr un.jamur tiram. 2005. Penebar swadaya. Jakarta.

Djarijah, Nunung M dan Abbas Siregar Djarijah. 2001. Budidaya jamur tiram.Yogyakarta : Kanisius

Muchtadi, dedy. 2010. Teknik Ealuasi Nilai Gizi Protein. Bandung: penerbit Alfabeta.

Sinaga M.S. 2007. Jamur Merang dan Budidayanya. Penebar Swadaya.Jakarta

Widiyastuti, B. 2002.Bududaya jamur kompos, jamur merang, jamur kancing

(champignon).Jakarta.:Penebar Swadaya

Widodo, R. (2010). Pemberian Makanan, Supleme dan Obat Pada Anak. Jakarta: Buku Kedokteran EGC. Hal.21-25.

Winarno,F.G.2014. Kimia Pangan dan Gizi. Jakarta: Gramedia Pustaka Utama. 